\title{
Comparing atmospheric trace element accumulation of three moss species
}

\author{
Doan Phan Thao Tien ${ }^{1}$, Le Hong Khiem ${ }^{2}$, Trinh Thi Thu Trinh ${ }^{3}$, Marina Vladimir Frontasyeva ${ }^{3}$, \\ Nguyen Thi Minh Sang ${ }^{4}$, Nguyen An Son ${ }^{4, *}$
}

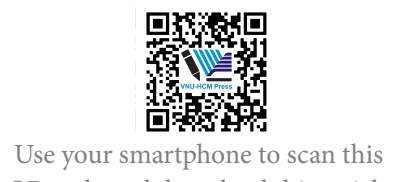

QR code and download this article

\begin{abstract}
${ }^{1}$ Nhatrang Institute of Technology
\end{abstract} Research and Application, VAST, Vietnam

${ }^{2}$ Institute of Physics of Vietnamese Academy of Science and Technology, Hanoi, Vietnam

${ }^{3}$ Frank Laboratory of Neutron Physics, Joint Institute for Nuclear Research, Dubna, Russia

${ }^{4}$ Dalat University, Dalat, Vietnam

\section{Correspondence}

Nguyen An Son, Dalat University, Dalat, Vietnam

Email: sonna@dlu.edu.vn

History

- Received: 2020-07-10

- Accepted: 2020-09-17

- Published: 2020-11-08

DOI : 10.32508/stdj.v23i4.2417

\section{Check for updates}

\section{Copyright}

(c) VNU-HCM Press. This is an openaccess article distributed under the terms of the Creative Commons Attribution 4.0 International license.

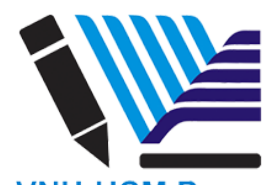

VNU-HCM Press

\begin{abstract}
Introduction: The intention of Vietnam to participate in the European-Asian Moss Survey in the framework of The United Nations Economic Commission for Europe - International Cooperative Programme on effects of air pollution on natural vegetation and crops (UNECE ICP Vegetation) necessitates choosing appropriate moss species that grow in the tropical and subtropical climate of Vietnam. The three selected moss species, divided into phytogeographical elements, were as follows: Leucobryum (aduncum, albidum), Hypnum commutatum and Barbula indica. Methods: The present study focuses on Central Vietnam where 18 samples of the three above moss species were collected in the vicinity of Dalat and Hue cities. Elements in the moss samples were detected by neutron activation analysis (NAA) at the IBR-2 reactor of the Division of Neutron Activation Analysis, Frank Laboratory of Neutron Physics, Joint Institute for Nuclear Research in Dubna, Russia. Results: The analytical results for twenty-three trace elements, which were used to study elemental accumulation abilities of the three moss species in the air, were $\mathrm{Na}, \mathrm{Mg}, \mathrm{Al}, \mathrm{Cl}, \mathrm{K}, \mathrm{Ca}, \mathrm{Ti}, \mathrm{V}, \mathrm{Mn}, \mathrm{Fe}, \mathrm{Co}, \mathrm{Zn}$, $\mathrm{As}, \mathrm{Br}, \mathrm{Rb}, \mathrm{Sr}, \mathrm{Sb}, \mathrm{I}, \mathrm{Cs}, \mathrm{Ba}$, La, Th, and U. The accumulation abilities were found to decrease in the following order: Leucobryum > Hypnum > Barbula. However, Leucobryum, because of its short stem, was not judged to be a suitable candidate for biomonitoring. Conclusion: The element accumulation abilities of Hypnum moss were better than those for Barbula, but both were comparable and could be used as indicators for air deposition monitoring; however, Hypnum was not widely present in Vietnam. Thus, Barbula indica moss could be used for performance of atmospheric deposition monitoring in Vietnam.
\end{abstract}

Key words: Leucobryum, Hypnum, Barbula, NAA, biomonitoring

\section{INTRODUCTION}

With rapid industrialization and a booming population, the environment in Vietnam has become seriously degraded in recent years ${ }^{1,2}$. The pilot study of Nguyen Viet et al. ${ }^{3}$ in the north of Vietnam found the moss technique to be an effective method to monitor metal air deposition. Three moss species are commonly recommended: Pleurozium schreberi, $\mathrm{Hy}$ locomium splendens and Scleropodium purum. These species are used for heavy element deposition monitoring in Europe. In addition, the moss Hypnum cupressiforme has been widely used ${ }^{2}$. However, the above-mentioned moss species are rarely found in Asia. Instead, other mosses, such as Hypnum plumaeforme, Taxithelium instratum, Thuidium tamariscellum and Barbula indica, have been used in Asian studies $^{3-7}$.

Generally, moss does not grow everywhere in Vietnam, and in many areas of the country, moss sites that strictly meet the recommendations for atmospheric deposition monitoring ${ }^{8}$ can rarely be found.
In our work, an attempt was made to compare three candidate moss species to study atmospheric deposition of heavy elements in Central Vietnam. The goal of this study was to find moss species growing widely in the special climate of Vietnam, which have good element accumulation abilities. Elemental concentrations were determined in 18 samples of three widespread mosses, Leucobryum (aduncum, albidum), Hypnum commutatum and Barbula indica, which were collected in Dalat and Hue. The elemental concentrations were then used to assess their element accumulation abilities.

\section{MATERIALS AND METHODS}

\section{SAMPLING AREAS}

Hue $\left(16.80^{\circ} \mathrm{N}, 108.20^{\circ} \mathrm{E}\right)$, with an area of roughly 84 $\mathrm{km}^{2}$, is a city in Thua Thien Hue province, located in the middle of Vietnam and situated on the Perfume River. The average elevation of the city is 3-4 meters above sea level. The region features a narrow coastal strip of land abutting the Truong Son Mountains. It 
has a tropical monsoon climate.

Dalat $\left(11.56^{\circ} \mathrm{N}, 108.27^{\circ} \mathrm{E}\right)$, with an area of about 390

$\mathrm{km}^{2}$, is a city in Lam Dong province in the Central Highlands of Vietnam, and situated at an elevation of 1500 meters above sea level. Dalat is considered a temperate region because of the effects of elevation and forest cover.

The two seasons (dry and rainy) in these areas occur at different times of the year because of their different geographical features. The rainy season in Dalat is from May to October, but in Hue it is from August to January.

\section{SAMPLING AND MOSS SPECIES}

The moss collection was carried out at the end of the rainy season in Dalat and Hue. To minimize the influence of the substrate, moss was collected from tree trunks at least $1.5 \mathrm{~m}$ above the ground and only the top, green part was used for analysis. The two sample groups (Dalat and Hue) were treated differently. The Dalat group was washed three times with distilled water to remove the substrate influence, but the Hue group was not washed. Using both washed and unwashed moss allows us to detect the influence of the heavy element deposition that covers the moss surface area.

In the Dalat area, seven moss samples (four Hypnum commutatum and three Leucobryum) were collected. In the Hue area, eleven moss samples (five Hypnum, two Leucobryum and four Barbula) were collected. The three moss species have distinctive morphologies, as shown in Figure 1.

Barbula commonly ranges from $1-3 \mathrm{~cm}$ high and, though rarely, can grow up to $5 \mathrm{~cm}$. Leaves are ovate to ovate-lanceolate, and the plant is green to brownish-green in color.

Leucobryum is a large genus of mostly tropical mosses that grow as compact cushions. The stem of Leucobryum albidum is less than $1 \mathrm{~cm}$ tall. Leucobryum aduncum is similar to Leucobryum albidum but is usually taller. Leucobryum albidum is the most abundant of the two species, and seems inappropriate for biomonitoring because of its short stem (only about $0.5 \mathrm{~cm}$ long).

\section{METHODS}

Neutron Activation Analysis was conducted at the Neutron Activation Analysis Division of the Frank Laboratory of Neutron Physics, Joint Institute for $\mathrm{Nu}$ clear Research, Dubna, Russia ${ }^{9}$. For short-term irradiation, about $0.3 \mathrm{~g}$ dry weight of moss sample was heat-sealed in polyethylene foil bags. For longterm irradiation, the moss samples were packed in aluminum cups. Samples were irradiated in channels equipped with a pneumatic system in the pulsed fast reactor IBR-2 at the Frank Laboratory of Neutron Physics. To determine short-lived isotopes, samples were irradiated for $3 \mathrm{~min}$ at channel 2 and then measured for $15 \mathrm{~min}$ after 3-5 min of decay. Longlived isotopes were determined using the Cd-screened channel 1. These samples were irradiated for 2.5 days and then re-packed after 3 days of decay. They were measured two times: the first time for 30 minutes just after the re-packaging; the second time was for 1.5 hours after 20 days of decay. Sample gamma spectra were obtained by measuring with a Germanium (Lithium) Detector with a resolution of $2.5-3 \mathrm{keV}$ for the ${ }^{60} \mathrm{Co} 1,332 \mathrm{keV}$ line, or a HPGe detector with a resolution of $1.9 \mathrm{KeV}$ for the ${ }^{60} \mathrm{Co} 1,332 \mathrm{keV}$ line. Data processing was conducted using software ${ }^{10} \mathrm{de}$ veloped at Frank Laboratory of Neutron Physics. Element concentrations were determined on the basis of certified reference materials and flux comparators. To maintain quality control, the contents of elements yielding short- and long-lived isotopes were measured using a collection of certified reference materials from the International Atomic Energy Agency (IAEA) and the United States National Institute of Standards and Technology (NIST).

\section{RESULTS}

Mosses obtain nutrients directly from atmospheric deposition because they lack a cuticle and a root system. Consequently, element accumulations in moss reflect atmospheric concentrations. However, the ability to accumulate elements in moss tissue can differ among species.

These data only show trends in element accumulation ability for these moss species. The calculated ratios cannot be used as recalibration factors for air deposition surveys using these moss types for the following reasons: only a small number of samples was used to calculate the factors, the samples were collected in urban and non-urban areas, the sampling did not always strictly follow the recommended procedures, and there considerable differences in morphology of these mosses which could cause great differences of element accumulation.

\section{DISCUSSION}

Hylocomium and Pleurozium mosses were used in biomonitoring in European countries, ${ }^{11}$ such as in Norway $^{12}$, Switzerland ${ }^{13}$; and those in northern Europe ${ }^{14}$. However, the first announcement about the moss technology in Northern Vietnam ${ }^{3}$ (Ha Noi and Thai Nguyen) was the use of Barbula moss. We have 


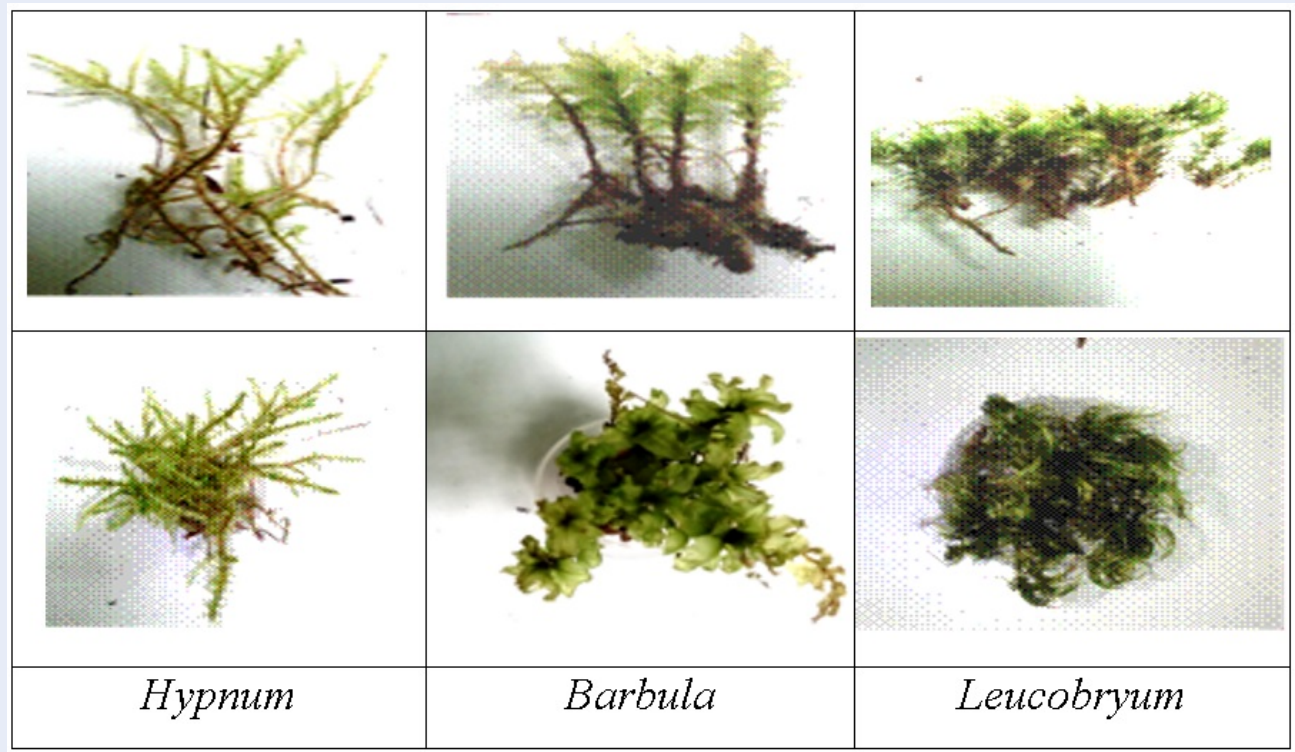

Figure 1: Side-view and top-view pictures of the three moss species. Hypnum usually grows in acidic environments, such as on tree trunks, walls, rocks and logs. Hypnum is about 2-10 cm tall, which is considered a small- to medium-sized moss.

analyzed and compared the ability accumulation of heavy metal of Hypnum moss between Viet Nam (Hue city) and Russia, Bosnia-Herzegovina ${ }^{15}$.

In this study, three kinds of mosses, which were collected in Da Lat (highlands) and in Hue, were analyzed by the NAA method. The element concentrations of mosses are displayed in Table 1; those values are used to study the elemental accumulation abilities of the moss species.

Essential and non-essential elements for plant life differ in abundance and behavior in moss tissue. Essential elements make up the majority of plant tissue and consist of the primary nutrients nitrogen $(\mathrm{N})$, phosphorus $(\mathrm{P})$, and potassium $(\mathrm{K})$. The secondary nutrients include calcium $(\mathrm{Ca})$, magnesium $(\mathrm{Mg})$ and sulfur (S), as well as the micronutrients iron $(\mathrm{Fe})$, manganese $(\mathrm{Mn})$, zinc $(\mathrm{Zn})$, copper $(\mathrm{Cu})$, boron $(\mathrm{B})$, and molybdenum (Mo). Elements having chemical properties homologous with those of these nutrients, especially the primary nutrients, can imitate them and accumulate in plant tissues. For example, some moss samples are rubidium and cesium imitate potassium, and barium and strontium imitate calcium. Although nutrients are essential elements, the imitators can be non-essential or toxic to plants. This information could be found anywhere in plant literature.

The Dalat and Hue sample groups were treated differently. In the Dalat sample group, the median concentrations of non-nutrient elements in the Leucobryum samples were higher than in the Hypnum samples. However, the inverse was the case for the primary, secondary nutrients and their homologous (except for potassium). In the Hue group, the median non - nutrient element concentrations in Barbula moss was lower than that of the Leucobryum and Hypnum mosses. In general, the non-nutrient elemental accumulation abilities of the mosses can be arranged in the following decreasing order: Leucobryum > Hypnum > Barbula.

The nutrient accumulation abilities of the different moss species are not the same. Most nutrients accumulate more in Hypnum than in the other species, and many of them accumulate more in Barbula than in Leucobryum.

Among the various moss types, the mean concentration of different elements were found in different magnitudes.

Table 2 shows the mean element concentration ratios of the moss pairs for Dalat and Hue. Except for a very high calcium ratio in Dalat, the Hypnum-Leucobryum ratios vary from 0.4 to 3.7 in Dalat, and from 0.5 to 2.6 in Hue. The ratios of the Barbula-Hypnum pair vary from 0.4-1.3 in the case of Hue. Results for washed moss samples may display real accumulation abilities of the moss types. The results of the non-washed moss samples may retain the influence of the substrate and a portion of the deposition covering the moss surface. 


\begin{tabular}{|c|c|c|c|c|c|c|c|}
\hline \multirow[t]{2}{*}{ Element } & \multicolumn{2}{|c|}{ Dalat (washed moss) } & \multirow[b]{2}{*}{$\begin{array}{c}\text { Error } \\
(\%)\end{array}$} & \multicolumn{4}{|c|}{ Hue (unwashed moss) } \\
\hline & $\begin{array}{l}\text { Hypnum } \\
\left(\mathrm{mg} \times \mathrm{kg}^{-1}\right)\end{array}$ & $\begin{array}{r}\text { Leucobryum } \\
\left(\mathrm{mg} \times \mathrm{kg}^{-1}\right)\end{array}$ & & $\begin{array}{l}\text { Hypnum } \\
\left(\mathrm{mg} \times \mathrm{kg}^{-1}\right)\end{array}$ & $\begin{array}{r}\text { Leucobryum } \\
\left(\mathrm{mg} \times \mathrm{kg}^{-1}\right)\end{array}$ & $\begin{array}{l}\text { Barbula } \\
\left(\mathrm{mg} \times \mathrm{kg}^{-1}\right)\end{array}$ & $\begin{array}{c}\text { Error } \\
(\%)\end{array}$ \\
\hline $\mathrm{Na}$ & 190 & 430 & 6 & 500 & 530 & 400 & 4 \\
\hline $\mathrm{Mg}$ & 1100 & 300 & 4 & 2860 & 1730 & 1310 & 4 \\
\hline $\mathrm{Al}$ & 630 & 1090 & 2 & 4300 & 7900 & 2900 & 2 \\
\hline $\mathrm{Cl}$ & 60 & 110 & 10 & 380 & 500 & 500 & 10 \\
\hline K & 4800 & 1900 & 10 & 12000 & 17200 & 11700 & 10 \\
\hline $\mathrm{Ca}$ & 14600 & 1100 & 6 & 13600 & 5300 & 9000 & 6 \\
\hline $\mathrm{Ti}$ & 20 & 40 & 18 & 280 & 500 & 400 & 18 \\
\hline V & 0.79 & 0.87 & 6 & 6.4 & 11.0 & 5.3 & 6 \\
\hline $\mathrm{Mn}$ & 32 & 15 & 5 & 123 & 48 & 89 & 5 \\
\hline $\mathrm{Fe}$ & 900 & 1400 & 13 & 2200 & 3100 & 1200 & 10 \\
\hline Co & 0.45 & 0.65 & 13 & 0.75 & 0.90 & 0.40 & 11 \\
\hline $\mathrm{Zn}$ & 55 & 35 & 12 & 120 & 80 & 120 & 8 \\
\hline As & 0.70 & 1.25 & 8 & 1.90 & 3.60 & 1.10 & 4 \\
\hline $\mathrm{Br}$ & 9 & 8 & 11 & 13 & 10 & 6 & 11 \\
\hline $\mathrm{Rb}$ & 16 & 14 & 25 & 23 & 30 & 11 & 18 \\
\hline $\mathrm{Sr}$ & 67 & $<15$ & 13 & 29 & 39 & 18 & 15 \\
\hline $\mathrm{Sb}$ & $<0.05$ & 0.20 & 25 & 0.90 & 0.80 & 1.30 & 9 \\
\hline I & 2.8 & 1.8 & 15 & 16 & 7 & 7 & 15 \\
\hline Cs & 0.50 & 0.30 & 12 & 0.55 & 0.90 & 0.20 & 7 \\
\hline $\mathrm{Ba}$ & 44 & $<18$ & 10 & 49 & 72 & 25 & 8 \\
\hline $\mathrm{La}$ & 0.6 & 1.3 & 12 & 2.6 & 5.2 & 1.2 & 7 \\
\hline Th & 0.35 & 1.00 & 7 & 1.15 & 2.50 & 0.50 & 4 \\
\hline $\mathrm{U}$ & 0.10 & 0.23 & 10 & 0.36 & 0.50 & 0.14 & 6 \\
\hline
\end{tabular}

The calcium ratio for Dalat is considerably larger than that for Hue. The high value could be caused by the high portion of calcium in the Bazan red soil and calcareous rocks of Dalat. These were compared with the low amount of calcium in the sandy coastal soil at Hue, and the presence of calcium on the surfaces of the unwashed moss samples.

Elemental accumulation abilities of Hypnum moss, which is largely used in Europe, are better than those of Barbula. However, Barbula moss is capable of accumulating pollutants, and is easily harvestable, recognizable and widespread ${ }^{3,15}$ in the whole country. Thus, Barbula moss would be an suitable bioindicator to study atmospheric deposition in Viet Nam.

\section{CONCLUSION}

Element accumulation abilities of Hypnum moss are better than for Barbula, but both of them are comparable and can be used as indicators for air deposition monitoring in Vietnam. Leucobryum, which is a short moss, does not appear to be appropriate for biomonitoring because of the strong influence of the substrate on the analytical results.

Except for the north of Vietnam, which has four seasons, other parts of Vietnam have two seasons (dry and rainy) per year that occur at different times. Consequently, the time selected for sampling in each region should take the dates of the local rainy season into consideration. 
Table 2: Mean element concentration ratios of moss pairs in Dalat and Hue

\begin{tabular}{|c|c|c|c|c|}
\hline Element & Dalat & & Hue & \\
\hline & $\mathrm{H} / \mathrm{L}$ & $\mathrm{H} / \mathrm{L}$ & $\mathrm{B} / \mathrm{L}$ & $\mathrm{H} / \mathrm{B}$ \\
\hline $\mathrm{K}$ & 2.5 & 0.7 & 0.7 & 1.0 \\
\hline $\mathrm{Ca}$ & 13.3 & 2.6 & 1.7 & 1.5 \\
\hline $\mathrm{Mg}$ & 3.7 & 1.7 & 0.8 & 2.2 \\
\hline $\mathrm{Fe}$ & 0.6 & 0.7 & 0.4 & 1.8 \\
\hline $\mathrm{Mn}$ & 2.2 & 2.6 & 1.9 & 1.4 \\
\hline $\mathrm{Zn}$ & 1.6 & 1.5 & 1.5 & 1.0 \\
\hline $\mathrm{Cl}$ & 0.5 & 0.8 & 1.0 & 0.8 \\
\hline $\mathrm{Na}$ & 0.4 & 0.9 & 0.8 & 1.3 \\
\hline $\mathrm{Al}$ & 0.6 & 0.5 & 0.4 & 1.5 \\
\hline $\mathrm{V}$ & 0.9 & 0.6 & 0.5 & 1.2 \\
\hline Co & 0.7 & 0.8 & 0.4 & 1.9 \\
\hline As & 0.6 & 0.5 & 0.3 & 1.7 \\
\hline $\mathrm{Br}$ & 1.1 & 1.2 & 0.6 & 2.0 \\
\hline $\mathrm{Rb}$ & 1.1 & 0.7 & 0.4 & 2.0 \\
\hline $\mathrm{Sr}$ & 4.4 & 0.7 & 0.5 & 1.6 \\
\hline I & 1.6 & 2.1 & 0.9 & 2.3 \\
\hline Cs & 1.7 & 0.6 & 0.2 & 2.8 \\
\hline $\mathrm{Ba}$ & 3.0 & 0.7 & 0.3 & 1.9 \\
\hline $\mathrm{La}$ & 0.5 & 0.5 & 0.2 & 2.2 \\
\hline Th & 0.4 & 0.5 & 0.2 & 2.3 \\
\hline $\mathrm{U}$ & 0.4 & 0.7 & 0.3 & 2.6 \\
\hline
\end{tabular}

H: Hypnym, L: Leucobryum, B: Barbula

Accumulation of nutrient elements in the studied moss species varies widely. It is preferable to use one of the same moss species to perform atmospheric deposition monitoring. Barbula moss can be used as the bio-indicator for monitoring air pollution in Vietnam because it has good elemental accumulation abilities and is widespread.

\section{COMPETING INTERESTS}

The authors commit that they have no competing interests.

\section{ACKNOWLEDGEMENTS}

The present research was carried out in the framework of the grant of the Plenipotentiary of Vietnam at JINR provided in 2018 and 2019.

This research is supported by the Ministry of Education and Training of Vietnam under the project code number: B2019 - DLA - 04.

We thank Steven Carlson who provided English language editing.

\section{REFERENCES}

1. ;Available from: https://www.who.int/vietnam/health-topics/ air-pollution.

2. Hoang TA, Chu NX, Tran TV. The Environmental Pollution in Vietnam: Source, Impact and remedies. International Journal of Scientific \& Technology Research. 2017;6(2). Available from: http://www.ijstr.org/final-print/feb2017/The-EnvironmentalPollution-In-Vietnam-Source-Impact-And-Remedies.pdf.

3. Nguyen VH, Frontasyeva MV, Trinh TTM, Gilbert D, Bernard N. Atmospheric heavy metal deposition in Northern Vietnam: Hanoi and Thainguyen case study using the moss biomonitoring technique, INAA and AAS. Environ Sci Pollut Res. 2010;17:1045-1052. PMID: 19924458. Available from: https: //doi.org/10.1007/s11356-009-0258-6.

4. Lee SL, Li X, Zhang G, Peng X, Zhang L. Biomonitoring of trace metals in the atmosphere using moss (Hypnum plumaeforme) in the Nanling Mountains and the Pearl River Delta, Southern China. Atmos Environ. 2005;39:397-407. Available from: https://doi.org/10.1016/j.atmosenv.2004.09.067.

5. Abdullah $M Z$, Saat $A B$, Hamzah ZB. Assessment of the impact of petroleum and petrochemical industries to the surrounding areas in Malaysia using mosses as bio-indicator supported by multivariate analysis. Environ Monit Assess. 2012;184:3959-3969. PMID: 21822578. Available from: https: //doi.org/10.1007/s10661-011-2236-y.

6. Munar MP, Oreiro RRB, Hipol RM. Ectohydric moss, Thuidium tamariscellum, monitors atmospheric lead $(\mathrm{Pb})$ pollution in Baguio City, Philippines. Tropical Plant Research. 2014;1:0407. Available from: http://www.tropicalplantresearch.com/ vol1Issue1/2.1.html.

7. Phan DTT, Trinh TTM, Khiem LH, Frontasyeva MV, Quyet $\mathrm{NH}$. Study of airborne trace element pollution in central and southern Vietnam using moss (Barbula indica) technique and neutron activation analysis. Asia-Pacific J Atmos Sci. 2019;55:247-253. Available from: https://doi.org/10.1007/ s13143-018-0065-4.

8. Reynolds B, Mills G, Pugh B. Monitoring of atmospheric heavy metal deposition in Europe using bryophytes. Experimental protocol 2000/2001survey UNECE, International cooperative program on effect of air pollution on natural vegetation and crops, Centre for Ecology and Hydrology, Bangor. 2001;Available from: http://nora.nerc.ac.uk/id/eprint/15072/1/ ICP_Vegetation_annual_report_2010-11.pdf.

9. Frontasyeva MV. Neutron activation analysis in the life sciences. A review. Physics of Particles and Nuclei. 2011;42:332-378. Available from: https://doi.org/10.1134/ S1063779611020043.

10. Pavlov SS, Dmitriev AY, Frontasyeva MV. Automation system for neutron activation analysis at the reactor IBR-2, Frank Laboratory of Neutron Physics, Joint Institute for Nuclear Research, Dubna, Russia. J Radioanal Nucl Chem. 2016;309:2738. PMID: 27375310. Available from: https://doi.org/10.1007/ s10967-016-4864-8.

11. Frontasyeva MV, Harmens $\mathrm{H}$. Monitoring of atmospheric deposition of heavy metals, nitrogen and pops in Europe using bryophytes, Monitoring manual 2015, International cooperative program on effect of air pollution on natural vegetation and crops, Centre for Ecology and Hydrology, Bangor. 2015;Available from: https://icpvegetation.ceh.ac.uk/sites/ default/files/Moss\%20protocol\%20manual.pdf.

12. Berg T, Steinnes E. Use of mosses (Hylocomium splendens and Pleurozium schreberi) as biomonitors of heavy metal deposition: from relative to absolute values. Environmental Pollution. 1997;98:61-71. Available from: https://doi.org/10.1016/ S0269-7491(97)00103-6. 
13. Thöni L, Schnyder N, Krieg F. Comparison of metal concentrations in three species of mosses and metal freights in bulk precipitation. Fresenius Journal of Analytical Chemistry. 1996;354:703-708. PMID: 15067476. Available from: https: //doi.org/10.1007/s0021663540703.

14. Reimann C, et al. Critical remarks on the use of terrestrial moss (Hylocomium splendens and Pleurozium schreberi) for monitoring of airborne pollution. Environmental pollution.
2001;113(1):41-57. Available from: https://doi.org/10.1016/ S0269-7491(00)00156-1.

15. Phan TTD, Van DD, Xuan VH, Le HK, Nguyet NTM. Comparison of ability absorption of heavy metal elements of Babula and Hypnum moss species by the neutron activation analusis method. Proceeding of Advances in Applied and Engineering Physics Hanoi. 2016;p. 465-469. 